\title{
Dr. Peter B.R. Allen, an Albertan Neurosurgeon: (1932 - 2013)
}

"PBR" Allen stands for "Peter Baker Roderick" Allen, one of Alberta's first homegrown neurosurgeons. Born in the mining town Wayne, Alberta (now a ghost town in the Badlands of Alberta) in 1932, Peter grew up in Coleman, located in Alberta's Rocky Mountains near Crowsnest Pass-another coal town. Underground mining was Peter's father's line of work. Peter, a good student and inspired by his town's doctor and surgeon, pursued high ambitions and attended the University of Alberta, graduating with a B.Sc. in 1954 and M.D. in 1956. Every summer, however, found Peter back in the mines in Crowsnest, working heavy equipment and earning his tuition. Peter interned in Edmonton and began his surgical training at the University of Alberta, winning the Royal College of Surgeon's coveted Medal of Surgery in 1958 for work on liver disease. Peter's plan had always been to return to Crowsnest as town doctor and surgeon. The Chief Surgeon at the University Hospital in Edmonton, Walter C. Mackenzie, recognized Peter's aptitude for surgery and came up with another plan.

Peter finished his basic training in neurosurgery under Guy Morton in Edmonton in 1960 and then following the advice of his bosses, Mackenzie and Morton, pursued a fellowship in neurosurgery at the famed Mayo Clinic under Dr. J. Grafton Love. He returned to Edmonton to start his neurosurgical practice in 1963, joining Guy Morton and Tom Speakman. And at the University of Alberta he remained until retirement in 2001. During the intervening 38 years Dr. Allen accomplished much.

Peter became the Divisional Director of Neurosurgery in 1969 and started up the first formal training program in Neurosurgery in Alberta under the auspices of the Royal College. In the meantime, Peter served as president of the Alberta and then Canadian Neurosurgical Societies, and was an examiner and then Chairman of the Examination Committee in Neurosurgery for the Royal College of Physicians and Surgeons of Canada.

National responsibilities aside, Peter was a highly regarded surgeon on his own turf. Wise, calm and always cheerful, a good listener, Peter was Vice President Medical at the University of Alberta Hospital during his tenure from 1985 to 1990. During that time, the Walter Mackenzie Health Sciences Centre was built, and Peter, a member of the hospital board, was instrumental in ensuring that a modern and fully equipped neurosurgical intensive care unit was part of the plan. In November 2012, the Neurosurgical Intensive Care Unit at the University of Alberta Hospital was officially named the Peter B.R. Allen Neurosciences Intensive Care Unit.

Perhaps Peter's greatest legacy was his surgical and clinical service in neurosurgery. A "surgeon's surgeon", Peter was a master in the operating room, and a superb instructor. His judgment was legendary, and his rapport with patients, their families, and coworkers of every type, unequalled. A product of his rural upbringing, Peter had an affection for the common person; no one was "ordinary" to Peter. He saw the whole patient and all of their concerns and fears, not just the neurosurgical condition he was called upon to treat.

Everyone loved the tall, handsome doctor "Peter Allen" and those of us still in the trenches live with that constant reminder when his former patients come for a follow-up or visit.

An equal legacy for Peter is his family. Looking after most of northern Alberta's neurosurgical patients, our province's first neurosurgical training program, and with significant national administrative responsibilities for a still young surgical specialty, Peter still managed to be the consummate family man. While in medical school, Peter ran the blood drive for the University of Alberta and asked the beautiful Barbara Beddome to be photographed donating blood for the campaign, Barbara having been Miss Grey Cup in that fall of 1955, (the Eskimos beat Montreal Alouettes 34 - 19 for the Grey Cup at Empire Stadium in Vancouver that year). As they were types $\mathrm{A}$ and $\mathrm{O}$ negative respectively, it seemed like a good match, and it was for over 55 years. Peter and Barbara raised a happy and successful family of four, the tribe now including 13 grandchildren and one great granddaughter.

Escaping the travails of brain surgery Peter enjoyed building airplanes, fixing cars, getting in his car for a very long adventure to some far off destination, and most of all, hiking in the mountains near Crowsnest Pass or Windermere Valley.

Peter's retirement was about as busy as his neurosurgical life, with interests in the History of Medicine and as Chairman of Alberta's Criminal Injuries Review Board, along with longawaited travels abroad and grandchildren to love.

Peter was a role model for young surgeons starting out, always friendly and generous, encouraging us to look for balance in our lives, and interested in our families. He promoted an attitude of cooperation among colleagues to benefit the overall practice of neurosurgery.

Peter Allen insisted he was simply lucky to have done so much from humble beginnings; his accomplishments were never something he was interested in talking about. Alberta was lucky to have raised, put to work, and known a man like Peter Allen.

Peter suffered bravely with cancer in the last months of his life and died on April 4th, 2013, just seven days short of his 81st birthday, surrounded by his family. A mountain of a man, Peter Allen, will be remembered. 